Article

\title{
A Turkey-origin H9N2 Avian Influenza Virus Shows Low Pathogenicity but Different Within-host Diversity in Experimentally Infected Turkeys, Quail and Ducks
}

\author{
Edyta Świętoń $^{1, *}$, Karolina Tarasiuk ${ }^{1}$, Monika Olszewska-Tomczyk ${ }^{1}$, Ewelina Iwan ${ }^{2}$ \\ and Krzysztof Śmietanka ${ }^{1}$ (D) \\ 1 Department of Poultry Diseases, National Veterinary Research Institute, Al. Partyzantów 57, \\ 24-100 Puławy, Poland; karolina.tarasiuk@piwet.pulawy.pl (K.T.); \\ monika.olszewska@piwet.pulawy.pl (M.O.-T.); ksmiet@piwet.pulawy.pl (K.Ś.) \\ 2 Department of Omics Analyses, National Veterinary Research Institute, Al. Partyzantów 57, \\ 24-100 Puławy, Poland; ewelina.iwan@piwet.pulawy.pl \\ * Correspondence: edyta.swieton@piwet.pulawy.pl
}

Received: 29 February 2020; Accepted: 14 March 2020; Published: 16 March 2020

\begin{abstract}
Avian influenza virus (AIV) is a highly diverse and widespread poultry pathogen. Its evolution and adaptation may be affected by multiple host and ecological factors, which are still poorly understood. In the present study, a turkey-origin H9N2 AIV was used as a model to investigate the within-host diversity of the virus in turkeys, quail and ducks in conjunction with the clinical course, shedding and seroconversion. Ten birds were inoculated oculonasally with a dose of $10^{6} \mathrm{EID}_{50}$ of the virus and monitored for 14 days. Virus shedding, transmission and seroconversion were evaluated, and swabs collected at selected time-points were characterized in deep sequencing to assess virus diversity. In general, the virus showed low pathogenicity for the examined bird species, but differences in shedding patterns, seroconversion and clinical outcome were noted. The highest heterogeneity of the virus population as measured by the number of single nucleotide polymorphisms and Shannon entropy was found in oropharyngeal swabs from quail, followed by turkeys and ducks. This suggests a strong bottleneck was imposed on the virus during replication in ducks, which can be explained by its poor adaptation and stronger selection pressure in waterfowl. The high within-host virus diversity in quail with high level of respiratory shedding and asymptomatic course of infection may contribute to our understanding of the role of quail as an intermediate host for adaptation of AIV to other species of poultry. In contrast, low virus complexity was observed in cloacal swabs, mainly from turkeys, showing that the within-host diversity may vary between different replication sites. Consequences of these observations on the virus evolution and adaptation require further investigation.
\end{abstract}

Keywords: avian influenza; pathogenicity; diversity; adaptation

\section{Introduction}

Influenza A viruses show the highest genetic diversity and the broadest host spectrum among the four known influenza virus types [1]. Classification of type A influenza viruses is based on differences in the structure of surface proteins - hemagglutinin (HA) and neuraminidase (NA). A wide range of influenza viruses is found in birds, which can harbour 16 subtypes of HA (H1-H16) and 9 subtypes of NA (N1-N9) in almost all possible configurations [2]. A vast majority of avian influenza viruses (AIV) occur naturally in wild waterfowl in a low pathogenic form (LPAIV) but events of 
transmission to domestic birds are occasionally reported [3-5]. Infections with LPAIV in wild birds are usually asymptomatic [6] but the clinical outcome in poultry varies and is highly dependent on host species. Chickens seem to be most resistant to LPAI infection among the gallinaceous poultry species [7]. Clinical manifestation of LPAI is common in turkeys, and usually involves respiratory system disorders [8,9] often aggravated by secondary bacterial infections [10]. In contrast, infected quail usually shed high amounts of virus in the absence of any clinical signs and mortality, therefore, it is thought that quail may support virus perpetuation and adaptation to other species of gallinaceous poultry [11,12].

The high diversity of influenza viruses confers their flexibility, enabling adaptation to novel conditions. The segmented RNA genome may undergo reassortment when two different influenza viruses infect the same cell, potentially generating progeny virions with beneficial gene constellations [13]. Furthermore, the error-prone viral polymerase introduces mutations into the newly synthetized genomes; therefore, the virus exists in a host as a complex swarm of similar but non-identical variants [14]. The heterogeneity and composition of a virus population is a combined effect of mutations generated during replication and selection pressure in the host, but may be also strongly affected by stochastic processes $[15,16]$. The spectrum of mutants in the virus population determines the adaptability of the virus to changing conditions such as immune response and switching the host species [17]. Therefore, studies on the within- and between-host virus diversity are crucial for the understanding of the virus adaptation, crossing host species barrier, and evolution phenomena $[18,19]$. This question has been investigated extensively in recent years in the case of influenza infections in humans and other mammals [20-25]. However, the within-host diversity of avian influenza viruses in birds is poorly explored, given the wide range of hosts and their manifold roles in the evolution and epidemiology of AIV. To address this question, we performed infection experiments in three common poultry species: turkeys, quail and ducks, using an H9N2 LPAIV of Y439-like lineage. The pathobiological features such as clinical signs, mortality, shedding and antibody levels were characterized in conjunction with the analysis of the virus population diversity in oropharyngeal and cloacal swabs.

\section{Materials and Methods}

\subsection{Virus Propagation}

The H9N2 low pathogenic avian influenza virus A/turkey/Poland/14/2013 used in the study was detected in an outbreak in a commercial turkey farm. Phylogenetic and molecular analysis showed that this strain originated from the wild-bird reservoir but acquired markers of adaptation to gallinaceous poultry [10]. The virus was propagated in 9-11-day-old embryonated specific pathogen free (SPF) chicken eggs. The virus stock was titrated by inoculation of SPF eggs with ten-fold dilutions of virus stock and the 50\% embryo infectious dose $\left(E^{2} D_{50}\right)$ was calculated with the Reed and Muench method.

\subsection{Birds and Infection Experiments}

Experiments were performed in 3-week-old Japanese quail, meat turkeys and Pekin ducks. Turkeys and ducks were purchased in local hatcheries and reared in the animal facility at the National Veterinary Research Institute (NVRI), Poland. Quail were obtained from a commercial farm at the age of two weeks and were housed for one week to allow acclimatization. The experiment for each species was conducted separately in the animal facility of BSL3+ containment level at NVRI. Birds were randomly allocated to three groups: inoculated (10 birds), contact ( 2 or 3 birds) and control ( 5 birds), and housed in separate rooms in metal grid cages. Water and feed were provided ad libitum. Prior to experimental inoculation, swabs and serum samples were collected and tested by means of real time RT-PCR and ELISA, respectively, in order to exclude any previous AIV infection.

Groups of ten birds were inoculated intranasally and intraocularly with the virus dose of $10^{6}$ EID $_{50}$ in $0.1 \mathrm{ml}$ divided equally between both infection routes ( $50 \mu \mathrm{l}$ split between the two nostrils and $50 \mu \mathrm{l}$ split between eyes, applied dropwise using a pipette). At 1 day post infection (dpi) three 
(ducks, turkeys) or two (quail) contact birds of the same species were introduced into the cage with inoculated birds. The control groups consisted of five mock-infected birds of the respective species. Birds were monitored for 14 days for the presence of clinical signs and mortality. At 2, 3, 4, 5, 6, 7, 10 and 14 dpi oropharyngeal and cloacal swabs were collected from all birds using commercial swabs with viral transport medium (Copan, Italy). Additionally, samples of lungs, trachea, duodenum, cecal tonsils and spleen were collected from a turkey that died during the experiment. At $14 \mathrm{dpi}$ blood samples were collected and birds were humanely euthanized.

The animal experiments were approved by the Local Ethical Committee (approval no. 88/2015 of 07 July 2015).

\subsection{Evaluation of Virus Shedding and Seroconversion}

Extraction of RNA from swab samples was performed with Viral Mini Kit (Syngen, Poland) according to the manufacturer's manual. The quantity of viral RNA was tested in one-step real time RT-PCR with primers and probe specific for the influenza M gene [26]. Reactions were performed using QuantiTect Probe RT-PCR Kit (Qiagen, Germany) in 7500 Fast Real Time PCR System (Applied Biosystems, USA) with the following protocol: $50^{\circ} \mathrm{C}$ for $30 \mathrm{~min}$ and $95^{\circ} \mathrm{C}$ for $15 \mathrm{~min}$ followed by 40 cycles of $95{ }^{\circ} \mathrm{C}$ for $10 \mathrm{~s}, 60{ }^{\circ} \mathrm{C}$ for $30 \mathrm{~s}$ and $72{ }^{\circ} \mathrm{C}$ for $10 \mathrm{~s}$. Ten-fold dilutions of the virus suspension used for inoculation were tested in parallel with the experimental samples to generate the standard curve. The quantity of viral RNA in swabs was expressed as equivalents of $\mathrm{EID}_{50}\left(\mathrm{eqEID}_{50}\right)$ in $1 \mathrm{~mL}$ of swab medium. Samples of organs collected from the dead turkey were homogenized in PBS to $20 \%$ (w/v) suspension and centrifuged $(2000 \mathrm{~g}, 10 \mathrm{~min})$. The RNA was extracted from the supernatant and the quantity of viral RNA in $0.1 \mathrm{~g}$ of organ was determined in real time RT-PCR as described above.

Sera collected from birds at $14 \mathrm{dpi}$ were tested with hemaglutination inhibition (HI) method using $\mathrm{A} /$ turkey/Poland/14/2013 antigen according to a standard procedure [27].

The shedding patterns in inoculated birds were characterized by the following parameters: latency period (time from inoculation to shedding), duration of shedding (number of days in which shedding was identified), peak shedding (maximum amount of virus excreted at any sampling day) and mean daily shedding (mean amount of virus excreted during the shedding period). Since some observations were right censored or interval censored, the following assumptions for the assessment of the duration of shedding were made: if shedding was detected at the last sampling day (14 dpi), this day was designated as the last day of shedding; if shedding stopped between two nonconsecutive sampling days, the last day with positive result was defined as the last day of shedding. The data were generated individually for each bird and shedding route, and mean and standard deviations were calculated.

\subsection{Deep Sequencing}

To compare the diversity of viral populations generated in the course of infection in the studied poultry species, swabs collected at 2 and $4 \mathrm{dpi}$, and the virus stock used for inoculation were subjected to deep sequencing.

The genome segments were amplified in RT-PCR using SuperScript III One-Step RT-PCR System with Platinum Taq High Fidelity DNA Polymerase (ThermoFisher Scientific) with primers annealing to the conservative $5^{\prime}$ and $3^{\prime}$ termini [28] modified to improve amplification of segments 1-3 [29]. In brief, two reactions were performed for each sample using primers MBTuni-12 (5'-ACGCGTGATCAGCRAAAGCAGG-3'), MBTuni-12G (5'-ACGCGTGATCAGCGAAAGCAGG-3') and MBTuni-13 (5'-ACGCGTGATCAGTAGAAACAAGG-3'). Primers MBTuni-12 and MBTuni-13 were used in the first reaction, and the second reaction, expected to favour amplification of long segments, contained primers MBTuni-12G and MBTuni-13. The products of both reactions were combined in equal volumes and cleaned with QIAquick PCR Purification Kit (Qiagen) according to the manufacturer's protocol. The quantity and purity of DNA was measured with NanoDrop 2000 (ThermoFisher Scientific) and Qubit fluorometer (ThermoFisher Scientific). Libraries were prepared 
using Nextera XT DNA Library Preparation Kit following the manufacturer's manual and their quality was examined with Fragment Analyzer (Advanced Analytical). Sequencing was performed in MiSeq (Illumina) using MiSeq Reagent Kit v3 (Illumina) with 1\% of sequencer throughput per sample.

\subsection{Sequencing Data Analysis}

The quality of raw data generated in MiSeq was evaluated with FastQC software (www. bioinformatics.babraham.ac.uk/projects/fastqc/). Adapters and low-quality fragments were removed with Trimmomatic [30] using 4-base sliding window and quality limit of 30. Only reads longer than 50 bases were retained. Filtered reads were mapped to the consensus sequence of the inoculum virus using BWA [31]. Samtools [32] was used to remove PCR duplicates from the alignment and realignment of reads was performed using LoFreq [33]. The output BAM files were processed with LoFreq and VarScan [34] to identify variants in the virus population with reference to the consensus sequence of the inoculum. Only variants identified by both programs, at positions with coverage of at least $500 \times$ and frequency above $2 \%$ were considered, except for those above $1 \%$ that were present at minimum $2 \%$ in another sample. The percentage values computed by VarScan were used in further analysis. The number of single-nucleotide polymorphisms (SNPs) was determined in each sample. Additionally, based on the SNPs frequency, the Shannon entropy was calculated for the virus population in each sample as previously described [35].

The nucleotide sequences were translated to amino acids for analysis of nonsynonymous substitutions. The H3 numbering scheme for the mature HA protein is used throughout the manuscript.

\subsection{Statistical Analysis}

The differences in the shedding parameters between species were assessed using U-Mann-Whitney test. The same test was used to compare shedding from respiratory tract and cloaca in each species separately. Comparison of the number of polymorphic positions and Shannon entropy values was also performed with the U-Mann-Whitney test. To evaluate the association between the quantity of viral RNA and the virus diversity in a sample, the Pearson correlation coefficient was calculated for eqEID ${ }_{50}$ and entropy values and was tested statistically. The $p$-value of $<0.05$ was considered statistically significant in all performed analyses, except for comparison of virus shedding between the three species, when the Bonferroni correction was applied due to multiple comparisons ( $p=0.05 / 2=0.025$ ).

\section{Results}

\subsection{Clinical Signs and Mortality}

No clinical signs or mortality were noted in quail and ducks. In turkeys, only slight apathy was observed from 2 dpi until the end of the experiment. One turkey died on 9 dpi. Slight duodenal congestion and cecum distension were found during necropsy. Viral RNA was detected in all sampled organs of this specimen, with the highest viral load in duodenum $\left(1 \times 10^{5} \mathrm{eqEID} \mathrm{E}_{50} / 0.1 \mathrm{~g}\right)$, then in lungs $\left(1.58 \times 10^{3}\right.$ eqEID $\left.50 / 0.1 \mathrm{~g}\right)$, spleen $\left(6.3 \times 10^{2}\right.$ eqEID $\left._{50} / 0.1 \mathrm{~g}\right)$, cecal tonsils $\left(63 \mathrm{eqEID}{ }_{50} / 0.1 \mathrm{~g}\right)$ and trachea $\left(25 \mathrm{eqEID} \mathrm{E}_{50} / 0.1 \mathrm{~g}\right)$.

\subsection{Virus Shedding}

\subsubsection{Turkeys}

In the challenged turkeys, shedding from respiratory tract was observed for the whole duration of the experiment (2-14 dpi), with all oropharyngeal swabs positive at 5-7 dpi (Table 1, Figure 1). Shedding from cloaca began later $(p<0.001)$ and was shorter in duration $(p<0.01)$ than oral shedding (Table 1). The overall level (peak and mean) of respiratory shedding was higher than from cloaca $(p<0.001)$. Oral shedding in contact turkeys was observed as soon as at $1 \mathrm{dpc}$ (days post contact) and continued until $13 \mathrm{dpc}$. Cloacal shedding in contact turkeys was noted at 2-9 dpc. 


\subsubsection{Quail}

Inoculated quail showed oral shedding between 2 and $6 \mathrm{dpi}$, and at 2-5 dpi viral RNA was detected in all oropharyngeal swabs (Table 1). Cloacal shedding was observed in a total of 6 birds. There was no significant difference in the latency between the oral and cloacal shedding but the former was longer $(p<0.01)$. The amount of virus excreted from respiratory tract was also higher than from cloaca ( $p<0.01$ for peak shedding and $p<0.001$ for mean shedding). In contact quail, oral and cloacal shedding was demonstrated at $4-5 \mathrm{dpc}$ and $2-3 \mathrm{dpc}$, respectively.

\subsubsection{Ducks}

Shedding from respiratory tract was observed in all inoculated ducks and cloacal shedding was found in a total of 8 birds (Table 1, Figure 1). There were no statistically significant differences in terms of the latency, duration and level of oral and cloacal shedding (Table 1). Contact ducks showed oral shedding from $3 \mathrm{dpc}$ and cloacal shedding began at $2 \mathrm{dpc}$, both continuing until $6 \mathrm{dpc}$.

Table 1. Shedding patterns in turkeys, quail and ducks infected with A/turkey/Poland/14/2013(H9N2). The number of swabs positive for viral RNA over the total number of swabs tested is presented. OP oropharyngeal swabs, CL - cloacal swabs, SD - standard deviation.

\begin{tabular}{|c|c|c|c|c|c|c|c|c|c|c|c|c|}
\hline \multirow{3}{*}{ dpi/dpc } & \multicolumn{4}{|c|}{ Turkeys } & \multicolumn{4}{|c|}{ Quail } & \multicolumn{4}{|c|}{ Ducks } \\
\hline & \multicolumn{2}{|c|}{ Inoculated } & \multicolumn{2}{|c|}{ Contact } & \multicolumn{2}{|c|}{ Inoculated } & \multicolumn{2}{|c|}{ Contact } & \multicolumn{2}{|c|}{ Inoculated } & \multicolumn{2}{|c|}{ Contact } \\
\hline & OP & CL & OP & CL & OP & CL & OP & CL & OP & CL & OP & CL \\
\hline $2 / 1$ & $9 / 10$ & $0 / 10$ & $2 / 3$ & $0 / 3$ & $10 / 10$ & $4 / 10$ & $0 / 2$ & $0 / 2$ & $7 / 10$ & $5 / 10$ & $0 / 3$ & $0 / 3$ \\
\hline $3 / 2$ & $9 / 10$ & $0 / 10$ & $3 / 3$ & $1 / 3$ & $10 / 10$ & $3 / 10$ & $0 / 2$ & $1 / 2$ & $5 / 10$ & $3 / 10$ & $0 / 3$ & $1 / 3$ \\
\hline $4 / 3$ & $9 / 10$ & $3 / 10$ & $3 / 3$ & $1 / 3$ & $10 / 10$ & $3 / 10$ & $0 / 2$ & $2 / 2$ & $8 / 10$ & $7 / 10$ & $3 / 3$ & $2 / 3$ \\
\hline $5 / 4$ & $10 / 10$ & $7 / 10$ & $3 / 3$ & $3 / 3$ & $10 / 10$ & $2 / 10$ & $2 / 2$ & $0 / 2$ & $2 / 10$ & $7 / 10$ & $3 / 3$ & $2 / 3$ \\
\hline $6 / 5$ & $10 / 10$ & $3 / 10$ & $3 / 3$ & $1 / 3$ & $7 / 10$ & $1 / 10$ & $1 / 2$ & $0 / 2$ & $0 / 10$ & $5 / 10$ & $2 / 3$ & $3 / 3$ \\
\hline $7 / 6$ & $10 / 10$ & $7 / 10$ & $3 / 3$ & $1 / 3$ & $0 / 10$ & $0 / 10$ & $0 / 2$ & $0 / 2$ & $0 / 10$ & $3 / 10$ & $2 / 3$ & $3 / 3$ \\
\hline $10 / 9$ & $5 / 9$ & $4 / 9$ & $2 / 3$ & $2 / 3$ & $0 / 10$ & $0 / 10$ & $0 / 2$ & $0 / 2$ & $0 / 10$ & $0 / 10$ & $0 / 3$ & $0 / 3$ \\
\hline $14 / 13$ & $5 / 9$ & $2 / 9$ & $2 / 3$ & $0 / 3$ & $0 / 10$ & $0 / 10$ & $0 / 2$ & $0 / 2$ & $0 / 10$ & $0 / 10$ & $0 / 3$ & $0 / 3$ \\
\hline Total & $10 / 10$ & $10 / 10$ & $3 / 3$ & $3 / 3$ & $10 / 10$ & $6 / 10$ & $2 / 2$ & $2 / 2$ & $10 / 10$ & $8 / 10$ & $3 / 3$ & $3 / 3$ \\
\hline Latency period [days (SD)] & $\begin{array}{c}2.3 \\
(0.9)\end{array}$ & $\begin{array}{c}5.3 \\
(1.3)\end{array}$ & & & $\begin{array}{c}2.0 \\
(0.0)\end{array}$ & $\begin{array}{c}2.5 \\
(0.8)\end{array}$ & & & $\begin{array}{c}2.5 \\
(0.8)\end{array}$ & $\begin{array}{c}2.6 \\
(0.9)\end{array}$ & & \\
\hline Duration of shedding [days (SD)] & $\begin{array}{l}10.3 \\
(4.2)\end{array}$ & $\begin{array}{c}4.2 \\
(3.3)\end{array}$ & & & $\begin{array}{c}4.7 \\
(0.5)\end{array}$ & $\begin{array}{c}1.3 \\
(1.6)\end{array}$ & & & $\begin{array}{c}2.2 \\
(0.9)\end{array}$ & $\begin{array}{c}3.0 \\
(2.0)\end{array}$ & & \\
\hline $\begin{array}{c}\text { Peak shedding } \\
{\left[\log _{10} \text { eqEID }{ }_{50} / 1 \mathrm{~mL}(\mathrm{SD})\right]}\end{array}$ & $\begin{array}{c}5.5 \\
(0.5)\end{array}$ & $\begin{array}{c}3.0 \\
(1.7)\end{array}$ & & & $\begin{array}{c}5.4 \\
(0.4)\end{array}$ & $\begin{array}{c}1.5 \\
(1.4)\end{array}$ & & & $\begin{array}{c}2.4 \\
(0.9)\end{array}$ & $\begin{array}{c}3.4 \\
(1.9)\end{array}$ & & \\
\hline $\begin{array}{c}\text { Mean daily shedding } \\
{\left[\log _{10} \text { eqEID } \mathrm{EI0}_{50} / 1 \mathrm{~mL}(\mathrm{SD})\right]}\end{array}$ & $\begin{array}{c}4.4 \\
(0.6)\end{array}$ & $\begin{array}{c}2.5 \\
(1.3)\end{array}$ & & & $\begin{array}{c}4.4 \\
(0.5)\end{array}$ & $\begin{array}{c}1.3 \\
(1.1)\end{array}$ & & & $\begin{array}{c}2.2 \\
(0.8)\end{array}$ & $\begin{array}{c}2.4 \\
(1.3)\end{array}$ & & \\
\hline
\end{tabular}

\subsubsection{Comparison of Shedding in Inoculated Turkeys, Quail and Ducks}

No significant differences in the latency of oropharyngeal shedding were observed between the tested species. However, both quail and ducks showed shorter latency period for cloacal shedding than turkeys ( $p<0.01$ and $p<0.001$, respectively) (Table 1 ). The highest duration of oral shedding was observed in turkeys and it was significantly longer than in quail $(p<0.01)$ and in ducks $(p<0.001)$. The statistically significant difference for the oral shedding duration was also noted between quail and ducks $(p<0.001)$. It was also demonstrated that cloacal shedding in turkeys was longer than in quail $(p<0.025)$. Comparison of the level of shedding (peak and mean daily shedding) showed no statistically significant differences for turkeys and quail, but both species shed higher amounts of virus via the respiratory route than ducks $(p<0.001)$. However, cloacal shedding in ducks was higher than in quail $(p<0.025)$, but it did not differ significantly from cloacal shedding in turkeys. 

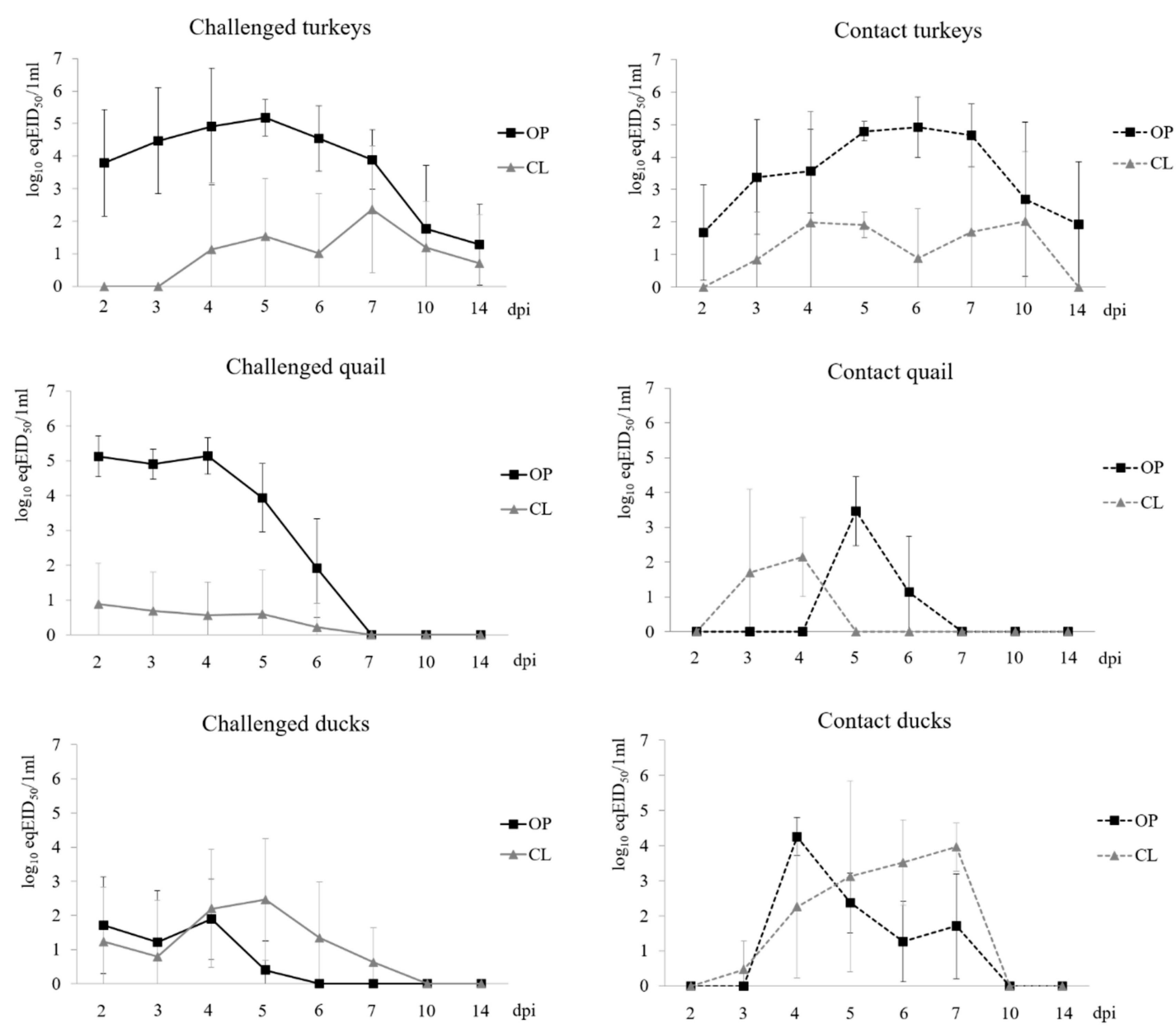

Figure 1. Shedding of H9N2 AIV in challenged (inoculated) and contact (secondarily exposed) turkeys, quail and ducks. OP - oropharyngeal swabs, CL - cloacal swabs.

\subsection{Antibody Response}

The HI test revealed seroconversion in all challenged and contact turkeys with titres ranging from $5 \log _{2}$ to $9 \log _{2}$. Positive results of HI test were also found in 7 out of 10 challenged quail and in both contact quail (titres $4-5 \log _{2}$ ). The lowest response was observed in ducks as five challenged and two contact birds seroconverted (titres $4-5 \log _{2}$ ).

\subsection{Diversity of Virus Population in Swabs}

In the case of quail, sequencing results were generated for all oropharyngeal swabs from both sampling points. No sequences from cloacal swabs from quail could be obtained due to very low viral load. Sequences of the excreted virus were obtained also for seven (out of nine) and eleven oropharyngeal swabs collected from turkeys at 2 and $4 \mathrm{dpi}$, respectively. Viruses from three cloacal swabs collected from turkeys at $4 \mathrm{dpi}$ were also sequenced. Samples from ducks, due to generally low viral load, were most problematic in sequencing. Only one sequence from $2 \mathrm{dpi}$ and eight sequences from 4 dpi ( $3 \mathrm{OP}$ and $5 \mathrm{CL}$ ) of sufficient quality were obtained. Additionally, sequencing of virus in cloacal swabs from ducks and turkeys from 5-7 dpi was also performed. For all of the samples tested, a high coverage was obtained for all segments of the viral genome (Supplementary Figure S1).

A total of 22 minority variants (i.e., $<50 \%$ ) were identified in the virus stock used for inoculation. Most of them were located in the HA gene. The highest number of single-nucleotide polymorphisms in the virus population was observed in quail, as 21-32 and 25-37 SNPs distributed across 172 nucleotide positions were identified at 2 and $4 \mathrm{dpi}$, respectively (Figure 2). These values were significantly higher than the number of SNPs found in oropharyngeal swabs from turkeys at $2 \mathrm{dpi}(10-22 ; p<0.01)$ and at 
4 dpi $(9-21 ; p<0.001)$. The virus population in the oropharyngeal swab from a duck at 2 dpi contained 20 SNPs and 9-16 SNPs were revealed at $4 \mathrm{dpi}$, which was significantly lower than in quail at $4 \mathrm{dpi}$ $(p<0.01)$ (Figure 2).
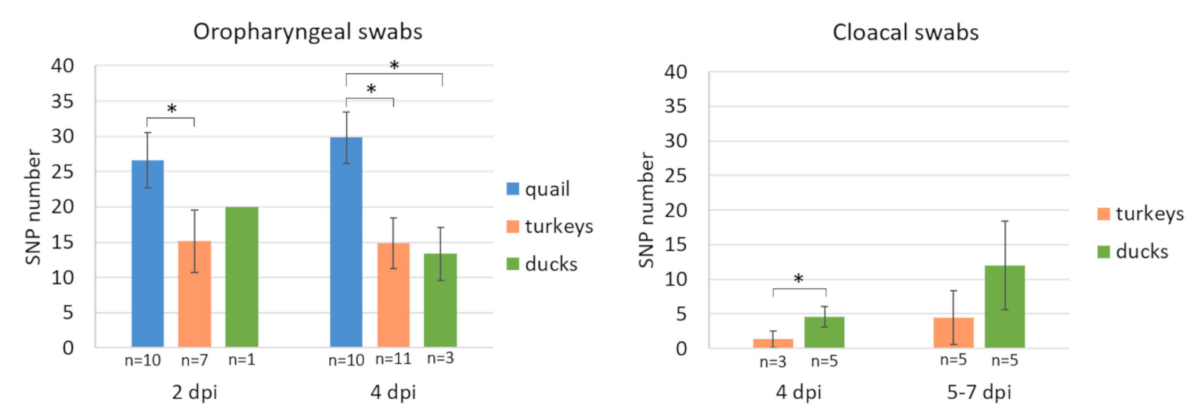

Figure 2. Average numbers of single nucleotide polymorphisms (SNPs) present in virus populations of oropharyngeal and cloacal swabs collected from birds infected with H9N2 AIV. The asterisks $\left({ }^{*}\right)$ show the statistically significant differences.

In contrast, virus populations in cloacal swabs collected at 4 dpi showed lower diversity, as a maximum of 2 SNPs and 4-7 SNPs were found in turkeys and ducks, respectively. In both species, these values were significantly lower than in oropharyngeal swabs $(p<0.05)$. To clarify whether this trend was maintained later during the course of infection, additional analysis of cloacal swabs collected between 5 and 7 dpi from turkeys $(n=5)$ and ducks $(n=5)$ was performed. An increase in the number of polymorphic sites was observed, but these were mainly newly emerged variants with low frequency $(<5 \%)$ (Figure 2).

Based on the frequency of variants in the virus population, the value of Shannon entropy was calculated for each sample and visualized with a heatmap (Figure 3). The results were in agreement with those obtained in the analysis of the SNPs numbers. The highest complexity of virus population was noted in oropharyngeal swabs from quail with significant differences compared to entropy in oropharyngeal swabs from turkeys ( $p<0.01$ at $2 \mathrm{dpi}$ and $4 \mathrm{dpi}$ ) and ducks ( $p<0.01$ at $4 \mathrm{dpi}$ ). The HA gene contributed mostly to the virus diversity in oropharyngeal swabs, while the lowest complexity was found for the PB1 and NS segments (Figure 3). In contrast, high homogeneity was observed in cloacal swabs collected at $4 \mathrm{dpi}$, followed by slight increase at $5-7 \mathrm{dpi}$ as a result of the emergence of new low-frequency polymorphisms (Figure 3 ). The scores for cloacal swabs from $4 \mathrm{dpi}$ were significantly lower than those for oropharyngeal swabs in both turkeys $(p<0.01)$ and ducks $(p<0.05)$.

\subsection{Synonymous and Nonsynonymous Mutations}

Nonsynonymous variants were present in 77 out of 172 polymorphic positions (44.8\%) identified in quail, including seven nonsynonymous mutations (PB2-A156V, PB1-K208R, HA-Y17H, HA-I30T, HA-L133R, HA-L133S, HA-T436I) derived from the parental stock. The highest proportion of nonsynonymous substitutions $(56.3 \%)$ was found in the HA gene. In turkeys the nonsynonymous polymorphisms represented 51.3\% (61/119) with seven mutations of inoculum-origin (PB2-A156V, PB1-K208R, HA-Y17H, HA-I30T, HA-L133R, HA-L133S, HA-T436I). The highest percentage of nonsynonymous substitutions was shown in ducks $(62.6 \%$; $82 / 131)$, wherein two of them were introduced with the inoculum material (HA-Y17H, HA-L133S).

None of the nonsynonymous mutations found in the HA protein have been linked to the increased affinity to mammalian-type sialic acid receptors. 

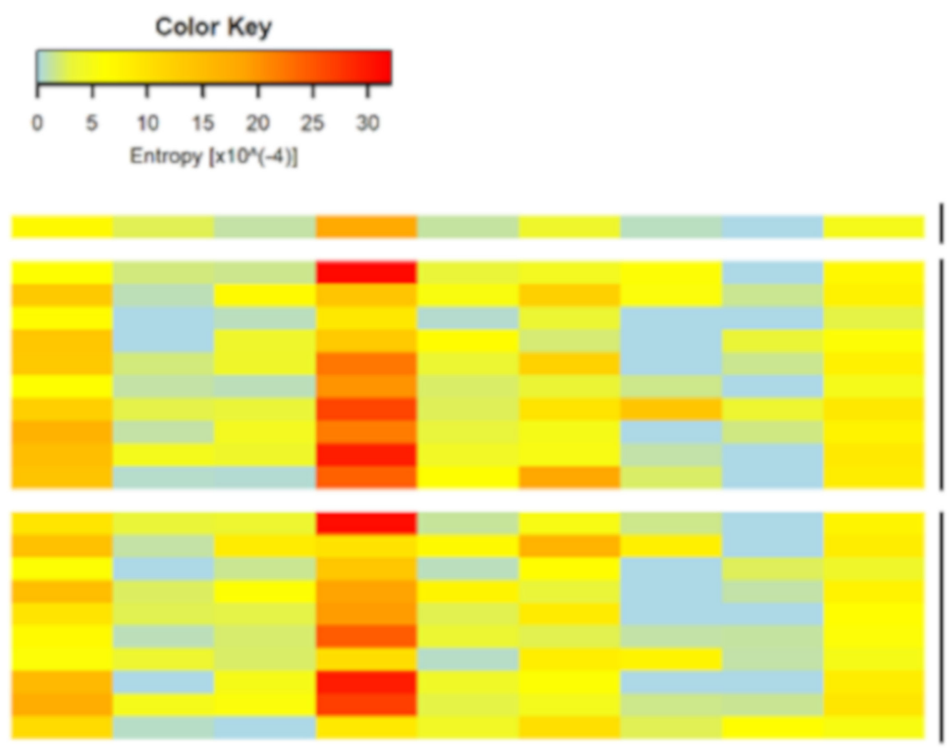

IN

quail OP

2 dpi

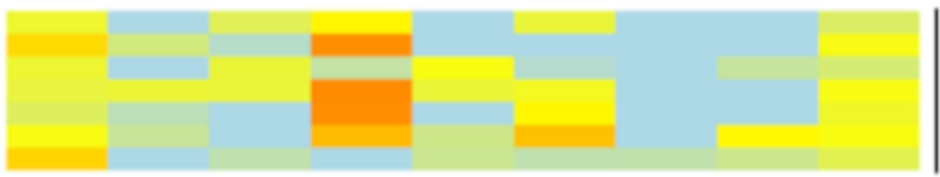

turkeys OP

2 dpi

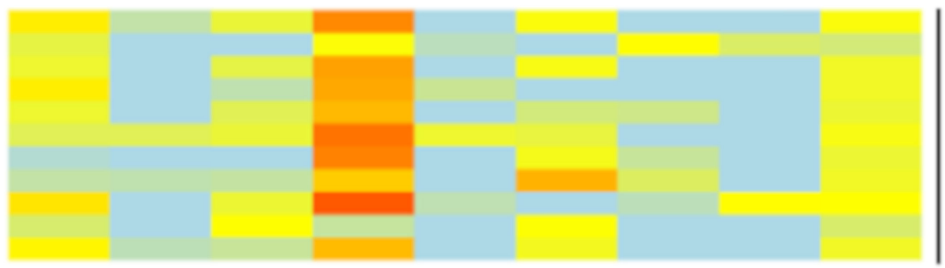

quail OP

4 dpi

turkeys OP

4 dpi

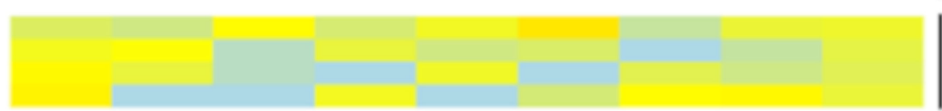

ducks OP

2 and 4 dpi

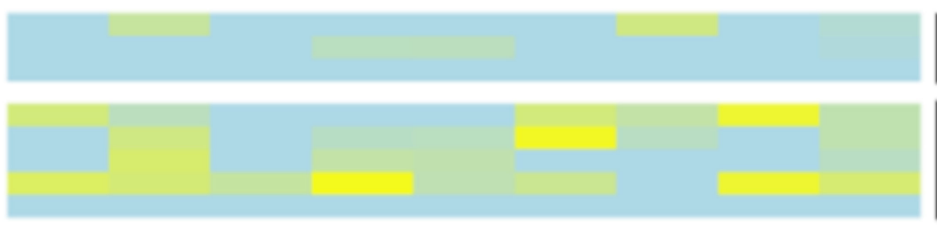

turkeys $\mathrm{CL}$

4 dpi

turkeys $\mathrm{CL}$

5-7 dpi

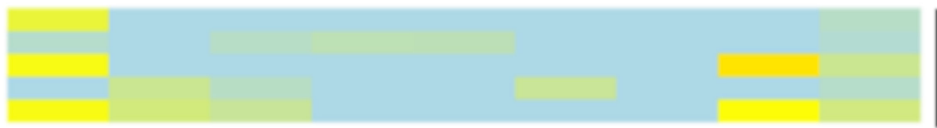

ducks $\mathrm{CL}$

4 dpi

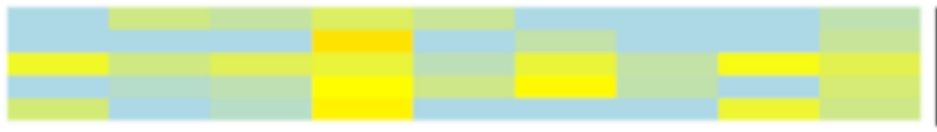

ducks $\mathrm{CL}$

5-7 dpi

PB2 PB1 PA HA NP NA M NS WG

Figure 3. Heatmap of Shannon entropy for each genome segment and the whole viral genome (WG) calculated from the frequencies of variants present in the virus population in oropharyngeal and cloacal swabs collected from turkeys, quail and ducks infected with H9N2 LPAIV. Each row refers to individual sample. IN - inoculum, OP - oropharyngeal swab, CL - cloacal swab.

\subsection{Changes in the Variant Frequency and Consensus-Level Substitutions}

The SNPs positions in the original virus stock and in swab samples were compared to differentiate mutations originating from the inoculum from those that arose in birds during infection. Out of 22 minority variants (i.e., $<50 \%$ ) present in the inoculum isolate, 21,20 and 9 were detected in quail, 
turkeys and ducks, respectively. A high variation in terms of the frequency of these variants in individual birds was observed (Figure 4).

In quail, changes in the consensus sequences resulted mostly from selection of inoculum-derived mutations, while the vast majority of novel variants were present at low frequencies $(<10 \%)$ (Figure 4). The consensus-level substitutions (i.e., $>50 \%$ ) were identified in 16 positions, including 4 nonsynonymous mutations, in a total of 7 birds. Except for the mutation in the NA position 534 , all these substitutions were present in the inoculum material as minority variants (Table 2, Supplementary Tables). Most of the newly acquired polymorphic sites were found in single birds while the inoculum-origin variants were usually shared by all birds (Figure 4). In contrast, 10 inoculum-independent mutations at the consensus level (4 nonsynonymous) were identified in oropharyngeal swabs from turkeys. Additionally, 16 inoculum-derived substitutions were found, including 6 nonsynonymous, which yielded consensus-level changes at a total of 26 genomic positions (Table 3, Supplementary Tables). In ducks, all low-frequency polymorphisms in the polymerase complex genes, NP, NA and M of the parental isolate were eliminated and only a part of variants in the HA gene was maintained, but they were selected to dominant levels only in two birds. Another two changes in the consensus sequences were noted in PB2 in cloacal swabs from 5-7 dpi (Table 4, Supplementary Tables). The most prominent changes in the dominant subpopulations were observed in cloacal swabs from turkeys. The inoculum variants were either eliminated or increased to a level of $100 \%$. However, there was no noticeable preference for particular variants in the gastrointestinal tract as different patterns were observed in individual birds. The most distinct set of mutations was found in a cloacal swab from a turkey that died at $9 \mathrm{dpi}$. The complete selection of variants occurred in nine genome positions, including several unique nonsynonymous mutations: E452V in PB2, R187K and K208R in PB1, L133R in HA (Table 3, Supplementary Tables). Interestingly, these substitutions were found also in the oropharyngeal swab from the same bird, but they were present only as low-frequency variants $(<5 \%)$.

Table 2. Changes in the consensus sequences in samples collected from quail infected with A/turkey/Poland/14/2013(H9N2).

\begin{tabular}{|c|c|c|c|}
\hline \multicolumn{4}{|c|}{ Quail - Oropharyngeal Swabs } \\
\hline Gene & Position & Amino acid Change & No. of Birds with Frequency $>50 \%$ at Any Day \\
\hline \multirow{4}{*}{ PB2 } & $303^{+}$ & - & 5 \\
\hline & $467^{\dagger}$ & A156V & 5 \\
\hline & $966^{+}$ & - & 6 \\
\hline & $2052^{+}$ & - & 5 \\
\hline \multirow[t]{2}{*}{ PA } & $948^{+}$ & - & 4 \\
\hline & $73^{+}$ & $\mathrm{Y} 17 \mathrm{H}$ & 7 \\
\hline \multirow{4}{*}{ HA } & $285^{+}$ & - & 6 \\
\hline & $363^{+}$ & - & 6 \\
\hline & $433^{+}$ & L133R & 7 \\
\hline & $434^{+}$ & L133S & 7 \\
\hline & $1260^{+}$ & - & 6 \\
\hline \multirow[t]{2}{*}{ NP } & $687^{+}$ & - & 3 \\
\hline & 534 & - & 1 \\
\hline \multirow[t]{2}{*}{ NA } & $540^{+}$ & - & 2 \\
\hline & $1218^{+}$ & - & 2 \\
\hline $\mathrm{M}$ & $486^{\dagger}$ & - & 1 \\
\hline
\end{tabular}


Table 3. Changes in the consensus sequences in samples collected from turkeys infected with A/turkey/Poland/14/2013(H9N2).

\begin{tabular}{|c|c|c|c|c|}
\hline \multirow{3}{*}{ Gene } & \multicolumn{3}{|c|}{ Turkeys } & \\
\hline & \multirow{2}{*}{ Position } & \multirow{2}{*}{ Amino Acid Change } & \multicolumn{2}{|c|}{ No. of Birds with Frequency $>50 \%$ at Any Day } \\
\hline & & & Oropharyngeal Swabs & Cloacal Swabs \\
\hline \multirow{7}{*}{ PB2 } & $303^{+}$ & - & 1 & - \\
\hline & $467^{+}$ & A156V & 1 & - \\
\hline & $654^{+}$ & - & 6 & 3 \\
\hline & 735 & - & 5 & 2 \\
\hline & $966^{+}$ & - & 4 & 2 \\
\hline & 1355 & $\mathrm{E} 452 \mathrm{~V}$ & - & 1 \\
\hline & 1740 & - & - & 1 \\
\hline \multirow{3}{*}{ PB1 } & $2052^{\dagger}$ & - & 1 & - \\
\hline & 560 & R187K & - & 1 \\
\hline & $623^{+}$ & K208R & - & 1 \\
\hline \multirow{5}{*}{ PA } & $1911^{\dagger}$ & - & - & 1 \\
\hline & 192 & - & 1 & - \\
\hline & 215 & L72S & 1 & - \\
\hline & 1680 & - & 1 & - \\
\hline & $73^{+}$ & Y17H & 10 & 4 \\
\hline \multirow{6}{*}{ HA } & $113^{+}$ & $\mathrm{I} 30 \mathrm{~T}$ & 1 & 1 \\
\hline & $285^{+}$ & - & 9 & 3 \\
\hline & $363^{+}$ & - & 9 & 3 \\
\hline & $433^{+}$ & L133S & 9 & 3 \\
\hline & $434^{+}$ & L133R & 10 & 4 \\
\hline & $1260^{\dagger}$ & - & 9 & 3 \\
\hline \multirow{3}{*}{ NP } & $1334^{\dagger}$ & T436I & 1 & 1 \\
\hline & $687^{\dagger}$ & - & 1 & 1 \\
\hline & 1396 & L466I & - & 1 \\
\hline \multirow{8}{*}{ NA } & 84 & - & 1 & - \\
\hline & $540^{\dagger}$ & - & 1 & 1 \\
\hline & 544 & G182S & 1 & - \\
\hline & 702 & - & 1 & - \\
\hline & 1114 & V372I & 1 & - \\
\hline & 1156 & V386I & 1 & - \\
\hline & 1203 & - & 5 & 2 \\
\hline & $1218^{\dagger}$ & - & 1 & 1 \\
\hline M & 699 & - & - & 1 \\
\hline
\end{tabular}

Table 4. Changes in the consensus sequences in samples collected from ducks infected with A/turkey/Poland/14/2013(H9N2).

\begin{tabular}{|c|c|c|c|c|}
\hline \multirow{3}{*}{ Gene } & \multicolumn{3}{|c|}{ Ducks } & \\
\hline & \multirow{2}{*}{ Position } & \multirow{2}{*}{ Amino Acid Change } & \multicolumn{2}{|c|}{ No. of Birds with Frequency $>50 \%$ at Any Day } \\
\hline & & & Oropharyngeal Swabs & Cloacal Swabs \\
\hline \multirow[t]{2}{*}{ PB2 } & 60 & - & - & 1 \\
\hline & 1139 & R380K & - & 1 \\
\hline \multirow{6}{*}{ HA } & $73^{+}$ & $\mathrm{Y} 17 \mathrm{H}$ & 1 & 2 \\
\hline & $285^{+}$ & - & 1 & 2 \\
\hline & $363^{+}$ & - & 1 & 2 \\
\hline & $433^{+}$ & \multirow{2}{*}{ L133S } & 1 & 2 \\
\hline & $434^{+}$ & & 1 & 2 \\
\hline & $1260^{+}$ & - & 1 & 2 \\
\hline
\end{tabular}



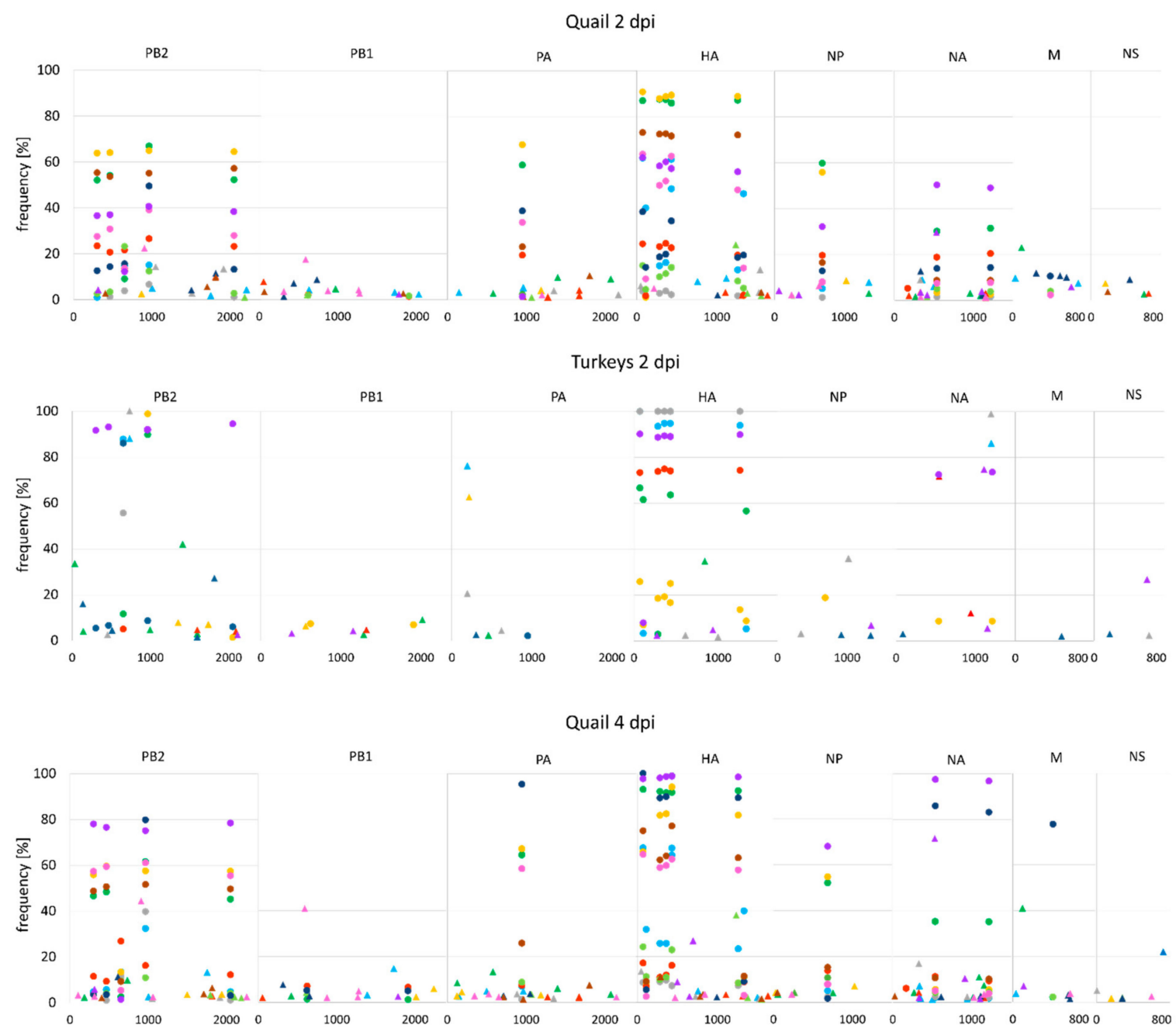

Turkeys $4 \mathrm{dpi}$

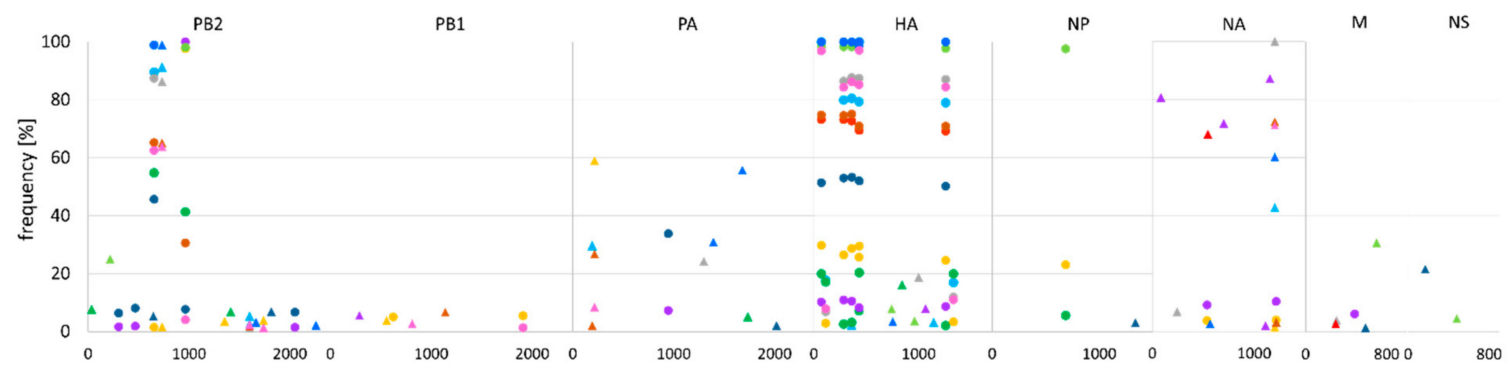

Figure 4. Distribution and frequency of variants in the virus population in oropharyngeal swabs collected from turkeys and quail infected with H9N2 AIV. The x-axis represents the genomic positions for each genome segment. Variants present in the same samples are showed with the same colour. Circles - variants of inoculum origin, triangles - variants that emerged during infection.

\subsection{Correlation Between Viral Load and Virus Diversity}

No significant correlation was observed between the entropy values and eqEID $\operatorname{En}_{50}$ in quail $(\mathrm{r}=0.23$, $p=0.3209)$, turkeys $(\mathrm{r}=0.25, p=0.2134)$ and ducks $(\mathrm{r}=-0.178, p=0.5421)$, indicating that the differences in the virus population diversity are independent of the differences in the virus replication level. 


\section{Discussion}

Evolution of viruses is a multifactorial process depending on the virus mutation rate, within-host replication dynamics, infection and transmission modes and other epidemiological and ecological factors [36-39]. These features seem particularly diverse in the case of AIV due to the broad range of susceptible host species and the high virus variability, therefore different AIVs may undergo distinct evolution patterns. For example, it has been shown that avian influenza viruses evolve faster in poultry than in wild birds, which could be partially explained by differences in the ecology of wild birds and poultry resulting in distinct contact rates and transmission routes [40]. The intra-host virus population diversity underlies and affects the between-host virus evolution in a long-term perspective. Therefore, investigations of the within-host virus diversity combined with the data on pathobiology and host ecology may contribute to the understanding of evolution of AIV in this heterogeneous host spectrum.

In the present study, three common poultry species were infected with an H9N2 AIV isolated from an outbreak in turkeys. Each bird was inoculated with the same virus stock, giving an opportunity to study both the pathogenicity of the virus and how its diversity had been fluctuating during the course of infection. Generally, the pathogenicity of the virus for the studied birds was low, although it varied between the species. Transmission occurred in all tested species as evidenced by shedding and seroconversion in contact birds. The levels of shedding in quail and turkeys were similar to those observed for LPAIV in gallinaceous poultry, i.e., higher amounts shed from respiratory tract than from cloaca [41]. There were no significant differences in the amount of virus shed in turkeys and quail but the former showed longer duration of both oropharyngeal and cloacal shedding. Turkeys were also the only species in which clinical symptoms and mortality were observed. However, the clinical outcome was much milder than in the previous study when infection of turkeys with the same AIV H9N2 strain was exacerbated by concomitant respiratory pathogens [10]. Infections with LPAIV in gallinaceous poultry are usually asymptomatic if uncomplicated, but in turkeys the clinical disease caused by the virus alone is often observed [9,42]. The long duration of respiratory shedding and the robust antibody response indicate that the H9N2 virus may readily infect turkeys and induce only non-specific clinical signs, enabling the spread of the virus within a flock. In addition, it was shown that the virus diversity was sustained during replication in the respiratory tract and a distinct set of novel consensus-level mutations emerged early in the experiment, suggesting a fast evolution of the virus in the course of infection.

The outcome of H9N2 AIV infection in quail, i.e., the lack of clinical signs with high level of respiratory shedding, is in agreement with the results of other experimental studies on the pathogenicity of LPAIV for this species [11,12]. It was shown that quail are susceptible to infections with most AIV subtypes of wild-bird and mammalian origin [12,43,44]; usually the infectious dose required for efficient replication is lower than for chickens and turkeys $[7,11]$ and shedding from respiratory tract is higher than in chickens [41]. Furthermore, quail may act as an intermediate host for adaptation of LPAIV from wild birds to other species of gallinaceous poultry and mammals [45-50]. The subclinical infections with high levels of shedding enabling prolonged circulation of the virus and the presence of both avian- and mammalian-type sialic acid receptors for influenza viruses in quail, are considered as the factors underlying the emergence of viruses with novel properties $[11,45,50]$. In the present study we showed that, apart from being an asymptomatic reservoir, quail may also support the maintenance and generation of high viral diversity, thus increasing the virus' adaptive potential. The high complexity of the virus population in oropharyngeal swabs from quail resulted mainly from the preservation and amplification of the original viral diversity, but quail showed also the highest propensity for the generation of novel low-frequency variants. Similar observations were made for Japanese quail infected with clade 2.3.4.4 H5N2 HPAIV as they showed the highest number of polymorphisms in the excreted virus among the tested minor gallinaceous poultry species and chickens [51]. Comparing to chickens and turkeys, the scale of domesticated quail production is small, but it is a common species in 
mixed backyard holdings, which may support the multipath evolution of the virus once it is introduced into the flock.

In contrast to quail and turkeys, there were no differences in the level of shedding by the oral and cloacal route in ducks, which is in agreement with the results of the meta-analysis performed for various species and LPAIV strain [41]. Furthermore, the high diversity of the inoculum virus was suppressed in ducks. This may have resulted from different selection pressures acting on the virus population in quail and turkeys (representatives of gallinaceous poultry) and genetically distant ducks (representatives of the anseriforms). Similarly, deep sequencing of samples collected from chickens and ferrets infected with a human-origin H7N9 AIV showed high virus heterogeneity in chickens and substantial loss of genetic variation in ferrets, which could be explained by low selection pressure in the natural avian host and strong bottleneck imposed by selection in mammals [18]. A similar effect was observed in chickens and mallards infected with a waterfowl-adapted H5N8 HPAIV, when high diversity of the virus was noted in mallards but lower diversity and higher deviation from the virus inoculum was revealed in chickens [52]. The same mechanism could underlie the severe decline of the inoculum-derived diversity observed in ducks, which were apparently an unfavourable environment for the H9N2 virus which, albeit primordially originating from wild waterfowl, had already undergone adaptation to gallinaceous poultry. A high number of novel variants, mostly nonsynonymous, which emerged in ducks, further supports the hypothesis of strong selection pressure.

Other interesting findings of the present study were the differences between the variability of virus population in oropharyngeal and cloacal swabs observed mainly in turkeys. The dominant population in cloacal swabs varied between individual birds, indicating that the low diversity could not be attributed to selection of specific variants conferring the best fitness in the gastrointestinal tract. However, a possible explanation of this phenomenon may lie in a "founder effect". In turkeys, the oropharyngeal shedding preceded the cloacal shedding, as shown by different latency periods, thus it could be expected that the virus population replicating in the intestines was founded by a small proportion of the population present in the respiratory tract, resulting in lower virus diversity. This observation is consistent with population genetics studies, as a spatial spread of a population results in a loss of genetic diversity, and similar effect could be also noticed in the case of dissemination of a virus within a single host [53]. Distinct patterns of AIV diversity in the two replication sites may potentially have consequences on the between-host diversity depending on the transmission route, e.g., in a situation of introduction of a virus with the aerosol route and a further spread of the virus in a flock with a faecal-oral route. Due to the oculonasal infection, the virus reached the respiratory tract first, therefore it would be highly desirable to perform a similar study with a different inoculation route, e.g., oral inoculation in the case of ducks. The experimental setup of the present study did not allow comparison of the diversity between the inoculated and contact birds due to the scarcity of sequences from the contact animals. However, qualitative examination of data generated for two contact turkeys and two contact ducks showed similar diversity in terms of the SNPs numbers and entropy values as those in inoculated birds.

The differences in the within-host virus diversity between the studied species could result from the characteristics of the virus strain used, high diversity of the inoculum stock, infection dose and inoculation route. Since no correlation was found between the virus load and virus diversity, it can be assumed that differences in virus complexity between species or sample types were not caused by differences in the replication level.

The limited number of studies on the diversity of AIV at the level of individual birds precludes drawing any far-reaching conclusions. Due to the differences in the experimental setup (e.g., infection with HPAI viruses $[51,52,54,55]$ ) and the methodology (e.g., data on the virus diversity obtained with deep sequencing [18,51,52], sequencing of amplicons cloned into plasmids [54] or analysis of double peaks in chromatograms [55]), results of these studies cannot be directly compared. However, we show that the within-host diversity of AIV varies between species and noticeable differences may be found 
even in the same host in various replication sites. Although no detailed analysis of selection pressures was performed in the study, the differences in the proportion of synonymous and nonsynonymous variants and in the number of consensus-level substitutions suggest that varying selection patterns were imposed on the virus population in each species. Further studies are necessary to assess the effect of these discrepancies on the between-host virus evolution and adaptation.

Supplementary Materials: The following are available online at http:/www.mdpi.com/1999-4915/12/3/319/s1.

Author Contributions: Conceptualization, E.Ś. and K.Ś.; Data curation, E.Ś.; Formal analysis, E.Ś. and K.Ś.; Investigation, E.Ś., K.T., M.O.-T., E.I. and K.Ś.; Methodology, E.Ś., K.T., M.O.-T and E.I.; Supervision, K.Ś.; Writing original draft, E.Ś.; Writing - review \& editing, E.Ś., K.T., M.O.-T., E.I. and K.Ś. All authors have read and agreed to the published version of the manuscript.

Funding: The study was supported by the National Science Centre in Poland (Grants no. 2015/17/N/NZ6/03515 and 2016/21/B/NZ6/01258).

Acknowledgments: We thank Elżbieta Juszczuk for excellent technical help.

Conflicts of Interest: The authors declare no conflict of interest.

\section{References}

1. Long, J.S.; Mistry, B.; Haslam, S.M.; Barclay, W.S. Host and viral determinants of influenza A virus species specificity. Nat. Rev. Microbiol. 2019, 17, 67-81. [CrossRef] [PubMed]

2. Fouchier, R.A.; Munster, V.J. Epidemiology of low pathogenic avian influenza viruses in wild birds. Rev. Sci. Tech. 2009, 28, 49-58. [CrossRef] [PubMed]

3. Probst, C.; Gethmann, J.M.; Petermann, H.J.; Neudecker, J.; Jacobsen, K.; Conraths, F.J. Low pathogenic avian influenza H7N7 in domestic poultry in Germany in 2011. Vet. Rec. 2012, 171, 624. [CrossRef] [PubMed]

4. Reid, S.M.; Brookes, S.M.; Núñez, A.; Banks, J.; Parker, C.D.; Ceeraz, V.; Russell, C.; Seekings, A.; Thomas, S.S.; Puranik, A.; et al. Detection of non-notifiable H4N6 avian influenza virus in poultry in Great Britain. Vet. Microbiol. 2018, 224, 107-115. [CrossRef]

5. Landman, W.J.M.; Germeraad, E.A.; Kense, M.J. An avian influenza virus H6N1 outbreak in commercial layers: Case report and reproduction of the disease. Avian Pathol. 2019, 48, 98-110. [CrossRef]

6. Kuiken, T. Is low pathogenic avian influenza virus virulent for wild waterbirds? Proc. Biol. Sci. 2013, 280, 20130990. [CrossRef]

7. Swayne, D.E.; Slemons, R.D. Using mean infectious dose of high- and low-pathogenicity avian influenza viruses originating from wild duck and poultry as one measure of infectivity and adaptation to poultry. Avian Dis. 2008, 52, 455-460. [CrossRef]

8. Corrand, L.; Delverdier, M.; Lucas, M.N.; Croville, G.; Facon, C.; Balloy, D.; Ducatez, M.; Guérin, J.L. A low-pathogenic avian influenza H6N1 outbreak in a turkey flock in France: A comprehensive case report. Avian Pathol. 2012, 41, 569-577. [CrossRef]

9. Spackman, E.; Gelb, J., Jr.; Preskenis, L.A.; Ladman, B.S.; Pope, C.R.; Pantin-Jackwood, M.J.; McKinley, E.T. The pathogenesis of low pathogenicity $\mathrm{H7}$ avian influenza viruses in chickens, ducks and turkeys. Virol. J. 2010, 7, 331. [CrossRef]

10. Śmietanka, K.; Minta, Z.; Świętoń, E.; Olszewska, M.; Jóźwiak, M.; Domańska-Blicharz, K.; Wyrostek, K.; Tomczyk, G.; Pikuła, A. Avian influenza H9N2 subtype in Poland - characterization of the isolates and evidence of concomitant infections. Avian Pathol. 2014, 43, 427-436. [CrossRef]

11. Bonfante, F.; Patrono, L.V.; Aiello, R.; Beato, M.S.; Terregino, C.; Capua, I. Susceptibility and intra-species transmission of the H9N2 G1 prototype lineage virus in Japanese quail and turkeys. Vet. Microbiol. 2013, 165, 177-183. [CrossRef] [PubMed]

12. Makarova, N.V.; Ozaki, H.; Kida, H.; Webster, R.G.; Perez, D.R. Replication and transmission of influenza viruses in Japanese quail. Virology. 2003, 310, 8-15. [CrossRef]

13. McDonald, S.M.; Nelson, M.I.; Turner, P.E.; Patton, J.T. Reassortment in segmented RNA viruses: Mechanisms and outcomes. Nat. Rev. Microbiol. 2016, 14, 448-460. [CrossRef] [PubMed]

14. Peck, K.M.; Lauring, A.S. Complexities of viral mutation rates. J. Virol. 2018, 92, e01031-17. [CrossRef]

15. McCrone, J.T.; Woods, R.J.; Martin, E.T.; Malosh, R.E.; Monto, A.S.; Lauring, A.S. Stochastic processes constrain the within and between host evolution of influenza virus. Elife. 2018, 7, e35962. [CrossRef] 
16. Zhao, L.; Abbasi, A.B.; Illingworth, C.J.R. Mutational load causes stochastic evolutionary outcomes in acute RNA viral infection. Virus Evol. 2019, 5, vez008. [CrossRef]

17. Lauring, A.S.; Andino, R. Quasispecies theory and the behavior of RNA viruses. PLoS Pathog. 2010, 6, e1001005. [CrossRef]

18. Zaraket, H.; Baranovich, T.; Kaplan, B.S.; Carter, R.; Song, M.S.; Paulson, J.C.; Rehg, J.E.; Bahl, J.; Crumpton, J.C.; Seiler, J.; et al. Mammalian adaptation of influenza A(H7N9) virus is limited by a narrow genetic bottleneck. Nat. Commun. 2015, 6, 6553. [CrossRef]

19. Xue, K.S.; Moncla, L.H.; Bedford, T.; Bloom, J.D. Within-host evolution of human influenza virus. Trends Microbiol. 2018, 26, 781-793. [CrossRef]

20. Sobel Leonard, A.; McClain, M.T.; Smith, G.J.; Wentworth, D.E.; Halpin, R.A.; Lin, X.; Ransier, A.; Stockwell, T.B.; Das, S.R.; Gilbert, A.S.; et al. Deep sequencing of influenza A virus from a human challenge study reveals a selective bottleneck and only limited intrahost genetic diversification. J. Virol. 2016, 90, 11247-11258. [CrossRef]

21. Barbezange, C.; Jones, L.; Blanc, H.; Isakov, O.; Celniker, G.; Enouf, V.; Shomron, N.; Vignuzzi, M.; van der Werf, S. Seasonal genetic drift of human influenza A virus quasispecies revealed by deep sequencing. Front. Microbiol. 2018, 9, 2596. [CrossRef] [PubMed]

22. Welkers, M.R.A.; Pawestri, H.A.; Fonville, J.M.; Sampurno, O.D.; Pater, M.; Holwerda, M.; Han, A.X.; Russell, C.A.; Jeeninga, R.E.; Setiawaty, V.; et al. Genetic diversity and host adaptation of avian H5N1 influenza viruses during human infection. Emerg. Microbes. Infect. 2019, 8, 262-271. [CrossRef] [PubMed]

23. Simon, B.; Pichon, M.; Valette, M.; Burfin, G.; Richard, M.; Lina, B.; Josset, L. Whole genome sequencing of A(H3N2) influenza viruses reveals variants associated with severity during the 2016-2017 season. Viruses 2019, 11, E108. [CrossRef] [PubMed]

24. Moncla, L.H.; Zhong, G.; Nelson, C.W.; Dinis, J.M.; Mutschler, J.; Hughes, A.L.; Watanabe, T.; Kawaoka, Y.; Friedrich, T.C. Selective bottlenecks shape evolutionary pathways taken during mammalian adaptation of a 1918-like avian influenza virus. Cell Host Microbe. 2016, 19, 169-180. [CrossRef] [PubMed]

25. Murcia, P.R.; Baillie, G.J.; Stack, J.C.; Jervis, C.; Elton, D.; Mumford, J.A.; Daly, J.; Kellam, P.; Grenfell, B.T.; Holmes, E.C.; et al. Evolution of equine influenza virus in vaccinated horses. J. Virol. 2013, 87, 4768-4771. [CrossRef]

26. Nagy, A.; Vostinakova, V.; Pirchanova, Z.; Cernikova, L.; Dirbakova, Z.; Mojzis, M.; Jirincova, H.; Havlickova, M.; Dan, A.; Ursu, K.; et al. Development and evaluation of a one-step real-time RT-PCR assay for universal detection of influenza A viruses from avian and mammal species. Arch. Virol. 2010, 155, 665-673. [CrossRef]

27. OIE. Manual of diagnostic tests and vaccines for terrestrial animals, chapter 3.3.4. "Avian influenza (infection with avian influenza viruses)". World Organization for Animal Health: Paris, France, 2018.

28. Zhou, B.; Donnelly, M.E.; Scholes, D.T.; St George, K.; Hatta, M.; Kawaoka, Y.; Wentworth, D.E. Single-reaction genomic amplification accelerates sequencing and vaccine production for classical and Swine origin human influenza A viruses. J. Virol. 2009, 83, 10309-10313. [CrossRef]

29. Watson, S.J.; Welkers, M.R.; Depledge, D.P.; Coulter, E.; Breuer, J.M.; de Jong, M.D.; Kellam, P. Viral population analysis and minority-variant detection using short read next-generation sequencing. Philos Trans $R$ Soc Lond B Biol Sci. 2013, 368, 20120205. [CrossRef]

30. Bolger, A.M.; Lohse, M.; Usadel, B. Trimmomatic: A flexible trimmer for Illumina sequence data. Bioinformatics. 2014, 30, 2114-2120. [CrossRef]

31. Li, H.; Durbin, R. Fast and accurate short read alignment with Burrows-Wheeler transform. Bioinformatics. 2009, 25, 1754-1760. [CrossRef]

32. Li, H.; Handsaker, B.; Wysoker, A.; Fennell, T.; Ruan, J.; Homer, N.; Marth, G.; Abecasis, G.; Durbin, R.; 1000 Genome Project Data Processing Subgroup. The Sequence Alignment/Map format and SAMtools. Bioinformatics 2009, 25, 2078-2079. [CrossRef] [PubMed]

33. Wilm, A.; Aw, P.P.; Bertrand, D.; Yeo, G.H.; Ong, S.H.; Wong, C.H.; Khor, C.C.; Petric, R.; Hibberd, M.L.; Nagarajan, N. LoFreq: A sequence-quality aware, ultra-sensitive variant caller for uncovering cell-population heterogeneity from high-throughput sequencing datasets. Nucleic Acids Res. 2012, 40,11189-11201. [CrossRef] [PubMed] 
34. Koboldt, D.C.; Chen, K.; Wylie, T.; Larson, D.E.; McLellan, M.D.; Mardis, E.R.; Weinstock, G.M.; Wilson, R.K.; Ding, L. VarScan: Variant detection in massively parallel sequencing of individual and pooled samples. Bioinformatics 2009, 25, 2283-2285. [CrossRef] [PubMed]

35. Milani, A.; Fusaro, A.; Bonfante, F.; Zamperin, G.; Salviato, A.; Mancin, M.; Mastrorilli, E.; Hughes, J.; Hussein, H.A.; Hassan, M.; et al. Vaccine immune pressure influences viral population complexity of avian influenza virus during infection. Vet. Microbiol. 2017, 203, 88-94. [CrossRef]

36. Sanjuán, R. From molecular genetics to phylodynamics: Evolutionary relevance of mutation rates across viruses. PLoS Pathog. 2012, 8, e1002685. [CrossRef]

37. Peck, K.M.; Chan, C.H.; Tanaka, M.M. Connecting within-host dynamics to the rate of viral molecular evolution. Virus Evol. 2015, 1, vev013. [CrossRef]

38. Hanada, K.; Suzuki, Y.; Gojobori, T. A large variation in the rates of synonymous substitution for RNA viruses and its relationship to a diversity of viral infection and transmission modes. Mol. Biol. Evol. 2004, 21, 1074-1080. [CrossRef]

39. Scholle, S.O.; Ypma, R.J.; Lloyd, A.L.; Koelle, K. Viral substitution rate variation can arise from the interplay between within-host and epidemiological dynamics. Am. Nat. 2013, 182, 494-513. [CrossRef]

40. Fourment, M.; Holmes, E.C. Avian influenza virus exhibits distinct evolutionary dynamics in wild birds and poultry. BMC Evol. Biol. 2015, 15, 120. [CrossRef]

41. Germeraad, E.A.; Sanders, P.; Hagenaars, T.J.; Jong, M.C.M.; Beerens, N.; Gonzales, J.L. Virus shedding of avian influenza in poultry: A systematic review and meta-analysis. Viruses 2019, 11, E812. [CrossRef]

42. Slomka, M.J.; Seekings, A.H.; Mahmood, S.; Thomas, S.; Puranik, A.; Watson, S.; Byrne, A.M.P.; Hicks, D.; Nunez, A.; Brown, I.H.; et al. Unexpected infection outcomes of China-origin H7N9 low pathogenicity avian influenza virus in turkeys. Sci. Rep. 2018, 8, 7322. [CrossRef] [PubMed]

43. Thontiravong, A.; Wannaratana, S.; Tantilertcharoen, R.; Prakairungnamthip, D.; Tuanudom, R.; Sasipreeyajan, J.; Pakpinyo, S.; Amonsin, A.; Kitikoon, P.; Oraveerakul, K. Comparative study of pandemic (H1N1) 2009, swine H1N1, and avian H3N2 influenza viral infections in quails. J. Vet. Sci. 2012, 13, 395-403. [CrossRef] [PubMed]

44. Vidaña, B.; Dolz, R.; Busquets, N.; Ramis, A.; Sánchez, R.; Rivas, R.; Valle, R.; Cordón, I.; Solanes, D.; Martínez, J.; et al. Transmission and immunopathology of the avian influenza virus A/Anhui/1/2013 (H7N9) human isolate in three commonly commercialized avian species. Zoonoses Public Health. 2018, 65, 312-321. [CrossRef] [PubMed]

45. Perez, D.R.; Lim, W.; Seiler, J.P.; Yi, G.; Peiris, M.; Shortridge, K.F.; Webster, R.G. Role of quail in the interspecies transmission of $\mathrm{H} 9$ influenza A viruses: Molecular changes on HA that correspond to adaptation from ducks to chickens. J. Virol. 2003, 77, 3148-3156. [CrossRef] [PubMed]

46. Sorrell, E.M.; Perez, D.R. Adaptation of influenza A/Mallard/Potsdam/178-4/83 H2N2 virus in Japanese quail leads to infection and transmission in chickens. Avian Dis. 2007, 51, 264-268. [CrossRef] [PubMed]

47. Hossain, M.J.; Hickman, D.; Perez, D.R. Evidence of expanded host range and mammalian-associated genetic changes in a duck H9N2 influenza virus following adaptation in quail and chickens. PLoS One. 2008, 3, e3170. [CrossRef]

48. Giannecchini, S.; Clausi, V.; Di Trani, L.; Falcone, E.; Terregino, C.; Toffan, A.; Cilloni, F.; Matrosovich, M.; Gambaryan, A.S.; Bovin, N.V.; et al. Molecular adaptation of an H7N3 wild duck influenza virus following experimental multiple passages in quail and turkey. Virology 2010, 408, 167-173. [CrossRef]

49. Yamada, S.; Shinya, K.; Takada, A.; Ito, T.; Suzuki, T.; Suzuki, Y.; Le, Q.M.; Ebina, M.; Kasai, N.; Kida, H.; et al. Adaptation of a duck influenza A virus in quail. J. Virol. 2012, 86, 1411-1420. [CrossRef]

50. Wan, H.; Perez, D.R. Quail carry sialic acid receptors compatible with binding of avian and human influenza viruses. Virology 2006, 346, 278-286. [CrossRef]

51. Bertran, K.; Lee, D.H.; Pantin-Jackwood, M.J.; Spackman, E.; Balzli, C.; Suarez, D.L.; Swayne, D.E. Pathobiology of clade 2.3.4.4 H5Nx high-pathogenicity avian influenza virus infections in minor gallinaceous poultry supports early backyard flock introductions in the Western United States in 2014-2015. J. Virol. 2017, 91, e00960-17. [CrossRef]

52. Leyson, C.; Youk, S.S.; Smith, D.; Dimitrov, K.; Lee, D.H.; Larsen, L.E.; Swayne, D.E.; Pantin-Jackwood, M.J. Pathogenicity and genomic changes of a 2016 European H5N8 highly pathogenic avian influenza virus (clade 2.3.4.4) in experimentally infected mallards and chickens. Virology 2019, 537, 172-185. [CrossRef] [PubMed] 
53. Gallagher, M.E.; Brooke, C.B.; Ke, R.; Koelle, K. Causes and consequences of spatial within-host viral spread. Viruses 2018, 10, E627. [CrossRef] [PubMed]

54. Iqbal, M.; Xiao, H.; Baillie, G.; Warry, A.; Essen, S.C.; Londt, B.; Brookes, S.M.; Brown, I.H.; McCauley, J.W. Within-host variation of avian influenza viruses. Philos. Trans. R. Soc. Lond. B, Biol. Sci. 2009, 364, 2739-2747. [CrossRef] [PubMed]

55. Hulse-Post, D.J.; Sturm-Ramirez, K.M.; Humberd, J.; Seiler, P.; Govorkova, E.A.; Krauss, S.; Scholtissek, C.; Puthavathana, P.; Buranathai, C.; Nguyen, T.D.; et al. Role of domestic ducks in the propagation and biological evolution of highly pathogenic H5N1 influenza viruses in Asia. Proc. Natl. Acad. Sci. USA 2005, 102, 10682-10687. [CrossRef] [PubMed]

(C) 2020 by the authors. Licensee MDPI, Basel, Switzerland. This article is an open access article distributed under the terms and conditions of the Creative Commons Attribution (CC BY) license (http://creativecommons.org/licenses/by/4.0/). 